\title{
WINTER FOOD HABITS OF THE COMMON REDPOLL AND THE HORNED LARK IN SASKATCHEWAN
}

\author{
by $M$. Larry Kerwin, Regina, Saskatchewan
}

Two species of winter birds that are commonly encountered in southern Saskatchewan along roadsides and in open fields are the Common Redpoll (Acanthis flamea) and the Horned Lark (Eremophila alpestris). The Redpoll is a winter visitant from the north. The Horned Lark is a summer resident which can be found through the winter (at least some years) in southwestern Saskatchewan. The literature suggests that during the winter months, weed seeds make up the bulk of the diet of both these species. This study, within 50 miles of Regina, suggests that the food used by these species in this part of Saskatchewan during the winter differs markedly from that reported in the literature.

\section{Methods}

Individuals of both species were collected between January 12 and March 24,1970 . In an attempt to reduce any bias introduced by the feeding behaviour of a certain flock no more than two individuals were taken from any one flock. In the case of the Horned Larks, flocks often consisted of fewer than 10 birds, whereas the Redpolls were generally in large flocks of from 50 to 150 birds. To study the birds' diets, food material from the esophagus and crop was removed, identified, air-dried at $60^{\circ} \mathrm{C}$ and weighed to the nearest milligram.

\section{Results and Discussion}

The results of the gravinetric analysis of the food material present in both the Redpolls and the Horned Larks is summarized in the Tables. Because of empty crops in some individuals, these results are based on a sample of 21 Redpolls and 16 Horned Larks.

Of the birds examined, the Common Redpolls showed a definite preference for the seeds of Russian Thistle ( $\mathrm{Sal}$ sola kali) while pigweed (Amaranthus sp.) and ragweed ( $A m b r o s i a s p$.) were of lesser importance. In contrast, Martin et al. (1951) report that Russian Thistle makes up less than 2 per cent of the winter diet of Redpolls. Pigweed is used from 5 to 10 per cent while ragweed makes up 50 per cent or more of their diet.

The reason for the significant discrepancy between our results and those reported by Martin et al. is not obvious. Perhaps it is a function of the small sample used in this study or perhaps it is a function of the availability of this food item in this area. The need for further study is indicated.

Table 1. Analysis of food habits of Common Redpoll.

\begin{tabular}{lcc}
\hline Food Item & $\begin{array}{r}\text { Per cent } \\
\text { Weight }\end{array}$ & $\begin{array}{c}\text { Per cent } \\
\text { Frequency }\end{array}$ \\
\hline $\begin{array}{l}\text { Russian thistle } \\
\text { (Salsola kali) }\end{array}$ & 95.9 & 100.0 \\
$\begin{array}{l}\text { Pigweed } \\
\text { (Amaranthus sp.) }\end{array}$ & 2.4 & 19.0 \\
$\begin{array}{l}\text { Ragweed } \\
\text { (Ambrosia sp.) }\end{array}$ & 1.7 & 14.3 \\
\hline
\end{tabular}

Table 2. Analysis of food habits of Horned Lark.

\begin{tabular}{lcc}
\hline Food Item & $\begin{array}{r}\text { Per cent } \\
\text { Weight }\end{array}$ & $\begin{array}{c}\text { Per cent } \\
\text { Frequency }\end{array}$ \\
\hline $\begin{array}{l}\text { Wheat } \\
\text { (Triticum sp.) }\end{array}$ & 96.1 & 100.0 \\
$\begin{array}{l}\text { Pigweed } \\
\text { (Amaranthus sp.) }\end{array}$ & 1.7 & 43.7 \\
$\begin{array}{l}\text { Ragweed } \\
\text { (Ambrosia sp.) }\end{array}$ & 0.7 & 18.8 \\
$\begin{array}{l}\text { Oats } \\
\text { (Avena sp.) }\end{array}$ & 0.5 & 6.2 \\
$\begin{array}{l}\text { Flax } \\
\text { (Linum sp.) }\end{array}$ & 0.4 & 6.2 \\
$\begin{array}{l}\text { Curled dock } \\
\text { (Rumex sp.) }\end{array}$ & 0.3 & 6.2 \\
$\begin{array}{l}\text { Bristlegrass } \\
\text { (Setaria sp.) }\end{array}$ & 0.3 & 6.2 \\
\hline
\end{tabular}


The most important food item in the diet of the Horned Larks collected during the study was commercial wheat (Triticum sp.). Again, this result differs from those reported in the literature (Martin et al., 1951; Bent, 1942; Godfrey, 1966) where weed seeds have been shown to make up the bulk of the winter diet of the Horned Lark.

While weed seeds are probably the main food of Horned Larks inhabiting native grasslands, it appears that in the cultivated fields near Regina they are taking advantage of the abundance of waste grain available along the roads and in the exposed portions of fields.

While wheat is equally as available to the Redpoll during the winter, wheat grains are undoubtedly toc large for them to handle. During winters of deep snow, the Horned Lark probably makes more use of weed seeds and at such times there may be some competition between the two species.

\section{Conclusion}

In the area studied for this report the most important food item in the winter diet of the Common Redpoll seems to be Russian Thistle, while wheat makes up the bulk of the winter diet of the Horned Lark. This is in disagreement with the reported literature and may be the result of the agricultural practices of the Regina area. Since only a small sample was studied, further work is needed to check the validity of these conclusions.

\section{LITERATURE CITED}

Bent, A. C. 1942. Life histories of North American flycatchers, larks, swallows, and their allies. U.S. Natl. Mus. Bull. 179. Washington, D.C.

Godfrey, W. E. 1966. The birds of Canada. Queen's Printer, Ottawa.

Martin, A. C., H. S. Zim, and A. L. Nelson. 1951. American wildlife and plants: a guide to wildlife food habits. Dover Publications, New York.

\section{FIRST CHIMNEY SWIFT RECORD FOR YORKTON DISTRICT}

\section{by Frank A. Switzer, 140 Logan Crescent West, Yorkton}

A dead male Chimney Swift was found in an active chimney at the farm of G. Switzer, eight miles east and seven miles south of Yorkton on July 15, 1967, during a routine chimney cleaning. There was no evidence of nest material present. The bird had evidently died quite recently and was well preserved, as evident from the enclosed photograph.

This is the first record for the Yorkton area, though specimens have been collected in the Pasquia Hills by Bard in 1937, and there are sight records for Indian Head, Regina and Cumberland House. The only nesting records for Saskatchewan to date are for Nipawin, where the late Maurice Street recorded nests in 1942 and 1943 and observed them as summer residents from 1937 to 1951.

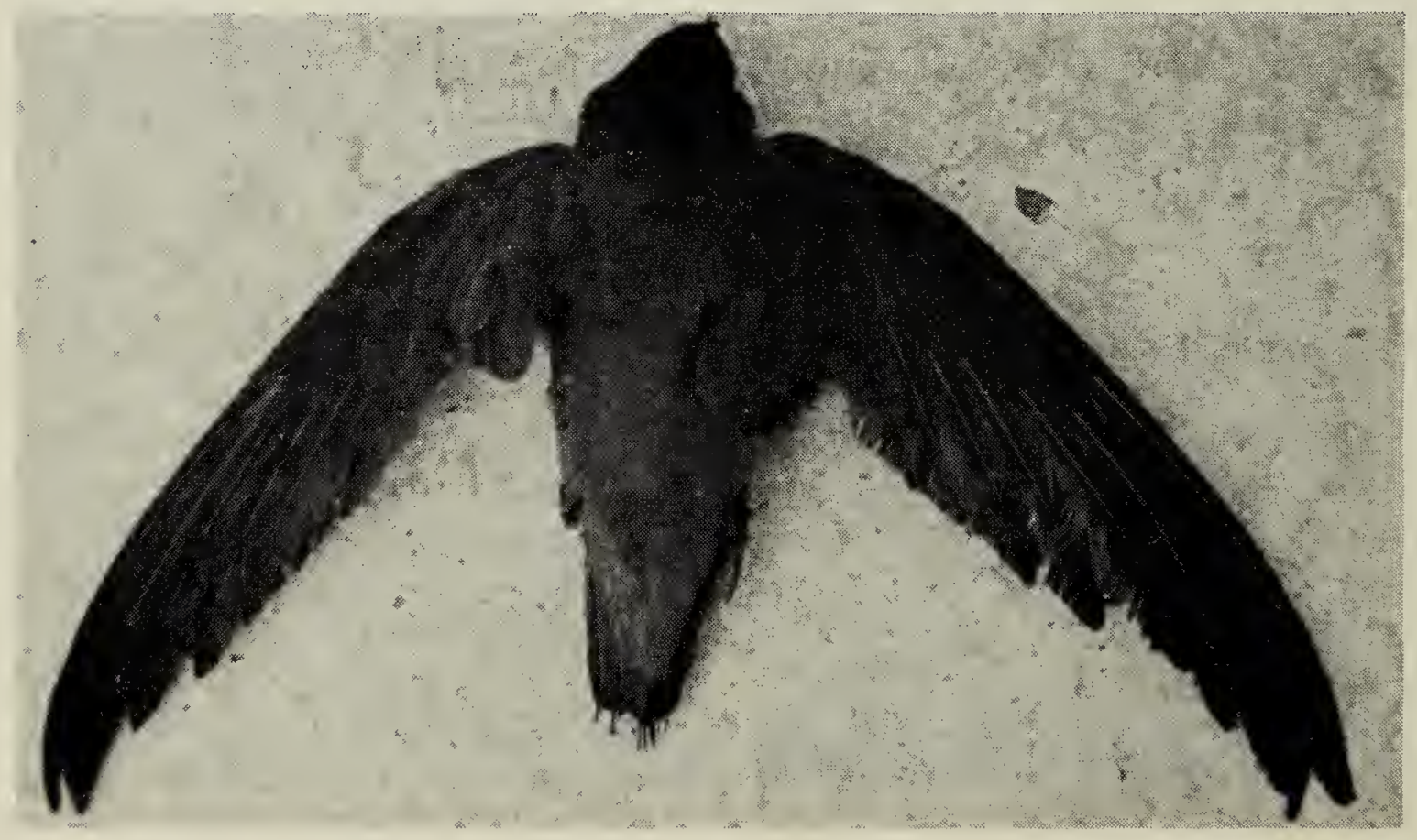

